\title{
Bioelectricity Production through Microbial Fuel Cell: Sustainable Energy Source
}

Kumar Gaurav

Amity Institute of Biotechnology, Amity University Haryana, Gurugram-122413, India

\section{To Cite this Article}

Kumar Gaurav, "Bioelectricity Production through Microbial Fuel Cell: Sustainable Energy Source", International Journal for Modern Trends in Science and Technology, 6(9): 73-76, 2020.

\section{Article Info}

Received on 10-August-2020, Revised on 18-August-2020, Accepted on 27-August-2020, Published on 04-September-2020.

\section{ABSTRACT}

Current world is facing the twin crisis of energy security due to depletion of non renewable energy sources and climate change caused by green house effect. This has led the researchers to think for various alternatives for sustainable energy production. Fuel cell technology has emerged as one of the potential options for generating clean and efficient energy. Microbial fuel cell (MFC) is a device for the conversion of chemical energy stored in organic compounds into electrical energy with the help of different microorganisms. For practical application of MFC, the main factors that are considered are efficiency and low costs. Efficiency of MFC is dependent on the effectiveness of the anode and cathode materials used in the fuel cell. In this review paper, various developments in electrode materials for microbial fuel cells (MFC) are discussed. Various modifications of anode and cathode materials for enhancement of power generation and simultaneous waste water treatment are also explored.

KEYWORDS: Bioenergy, Proton-exchange membrane, Microbial fuel cell, Mediator, Electrode material

\section{INTRODUCTION}

Microbial fuel cell (MFC) is green and renewable source of energy for electricity production. It converts the chemical energy (in organic and inorganic compound) to electrical energy through redox reaction by microorganism under anaerobic conditions [1]. MFC consist of anodic chamber (anaerobic) and cathodic chamber (aerobic) separated by proton exchange system (PES) or salt bridge. Microorganism removes electron from organic matter and proton from organic matter and transfers these electrons to anode in anodic chamber while protons are transferred through PES to cathodic chamber. The electrons are transported to cathode through an electrical circuit and combine with proton to form water [2, 3]. MFC is used as for waste water treatment and electricity generation simultaneously [4]. It can be also used as biosensor.

\section{MFC COMPONENTS}

A typical MFC consists of anodic and cathodic chamber separated by proton exchange system (PES) or salt bridge (Table 1). PES is responsible for transfer of proton from anodic to cathodic chamber. PES system should ideally be able to inhibit the transfer of other material such as fuel (substrate) or electron acceptor (oxygen) while conducting protons to cathode at high efficiency. PES may be proton exchange membrane (PEM) or salt bridge. Proton exchange membranes are cation exchange membrane such as Nafion or Ultrex. Nafion is the most popular because of its permeability of protons. Salt-bridge, device used to connect the oxidation reduction half cells of galvanic cells. It consists of a U-shaped glass tube filled with inert electrolyte $\mathrm{KCl}$ or $\mathrm{NaCl}$. The 
electrolyte is often gelified with agar to help prevent the intermixing of fluids which might otherwise occur. The conductivity of a glass tube bridge depends mostly on the concentration of the electrolyte $(\mathrm{NaCl}$ or $\mathrm{KCl})$. Salt bridge can be prepared with various molar concentration 1,3,5, 7 $\mathrm{M} \mathrm{NaCl}$ or $\mathrm{KCl}$ with agar concentration of $10 \%$. The salt concentration varied in agar salt bridge from $1 \%$ to $10 \%$, the volumetric power density changed from 1.71 to $84.99 \mathrm{~mW} / \mathrm{m}^{3}$ and power density varies from 0.32 to $16.02 \mathrm{~mW} / \mathrm{m}^{2}$. Generally, the maximum power density was observed at $5 \%$ salt concentration with $10 \%$ agar. Anode and cathode is made of graphite, graphite felt, carbon paper, carbon cloth, Pt and Pt-black. MFC with Pt or Ptcoated electrodes are superior to graphite, graphite felt and carbon cloth and provides higher power density than those with graphite or graphite felt electrodes.

Table 1: Basic component of MFC

\begin{tabular}{|c|c|}
\hline Items & Materials used \\
\hline $\begin{array}{c}\text { Anodic } \\
\text { chamber }\end{array}$ & Glass, pexiglass, polycarbonate \\
\hline $\begin{array}{c}\text { Cathodic } \\
\text { chamber }\end{array}$ & Glass, pexiglass, polycarbonate \\
\hline Anode & $\begin{array}{c}\text { Graphite, graphite felt, carbon } \\
\text { paper, carbon cloth, Pt, Pt-black, } \\
\text { reticulated vitreous carbon } \\
\text { (RVC) }\end{array}$ \\
\hline Cathode & $\begin{array}{c}\text { Graphite, graphite felt, carbon } \\
\text { paper, carbon cloth, Pt, Pt-black, } \\
\text { reticulated vitreous carbon } \\
\text { (RVC) }\end{array}$ \\
\hline $\begin{array}{c}\text { Proton } \\
\text { exchange } \\
\text { system }\end{array}$ & $\begin{array}{c}\text { Proton exchange membrane } \\
\text { (Nafion, Ultrex), salt bridge }\end{array}$ \\
\hline
\end{tabular}

\section{MEDIATOR (EXOGENOUS) AND MEDIATOR-LESS MFC}

Microorganisms are incapable of transferring electrons directly to the anode because outer layer of microbial species are composed of non-conductive lipid membrane (peptidoglycan and lipopolysaccharide) that hinders the direct electron transfer to the anode. Mediator in oxidized state in anodic chamber and can be easily reduced by capturing electrons within membrane. The mediator with electron moves across the membrane and releases the electrons to anode and become oxidized in the anodic chamber. The typical synthetic exogenous mediators include dyes and metallorganics such as neutral red, methylene blue, thionine, Fe(II) EDTA, 2-hydroxy-1-4, napthoquinone. The naturally occurring compounds such as humic acid, oxyanions of sulphate and thiosulphate can also be act as mediator and they have ability to transfer electron from inside the cell membrane to the anode. Microorganisms (Geobacter metallireducens, Geobacteraceae sulferreducens, Clostridium butyricum, Rhodoferax ferrireducens and Shewanella putrefaciens) transferred electrons directly to anode, MFC called mediator-less MFCs and bacteria known as exoelectrogens. Exoelectrogens microbes produce nanowires and uses electrochemically redox enzyme in their outer membrane that allows the electron transfer to anode. These microbes are operationally stable and provide high efficiency.

Basically, the power output from MFC depends upon the rate of degradation of fuel, rate of electron transfer to anode, rate of proton transfer to cathodic chamber, circuit resistance, electrode materials, configuration and operating condition [5]. In MFC, anodic chamber consist of fuel (glucose, acetate, sucrose, starch, molasses, lactate maltose, xylose etc.), anode and microbial consortium (Table 2). Fuel type, concentration and feed rate are important factors that impact the performance of MFC. Generally, a higher fuel concentration yields higher power output and it was reported that power density increases with increase in fuel concentration. High feed rate promoted the growth of fermentative bacteria.

Table 2: Microbes in microbial fuel cell

\begin{tabular}{|c|c|}
\hline Microbes & Fuel/Substrate \\
\hline \multicolumn{2}{|c|}{ Mediator- added MFC } \\
\hline Pseudomonas aeruginosa & Glucose \\
\hline Escherichia coli & $\begin{array}{l}\text { Glucose, } \\
\text { sucrose }\end{array}$ \\
\hline Lactobacillus plantarum & Glucose \\
\hline Streptococcus lactis & Glucose \\
\hline Klebsiella pneumoniae & Glucose \\
\hline Proteus mirabilis & Glucose \\
\hline \multicolumn{2}{|c|}{ Mediator- less MFC } \\
\hline Geobacter metallireducens & Acetate \\
\hline $\begin{array}{c}\text { Geobacteraceae } \\
\text { sulferreducens }\end{array}$ & Acetate \\
\hline Rhodoferax ferrireducens & $\begin{array}{c}\text { Glucose, xylose, } \\
\text { sucrose, } \\
\text { maltose }\end{array}$ \\
\hline Shewanella putrefaciens & $\begin{array}{l}\text { Lactate, } \\
\text { pyruvate }\end{array}$ \\
\hline Aeromonas hydrophila & Acetate \\
\hline
\end{tabular}

\section{ANODIC MATERIALS IN MFC}

Electrode is an important key material for 
performance and cost of MFCs. Over the last decade, different types of electrode material its configuration was studied. The electrode can be classified as chemical and bio-electrode. Electrode materials should have the some following general properties; (a) low cost; (b) good electrical conductivity; (c) high mechanical strength; (d) good chemical stability; (e) anti-corrosion and (f) high surface area. Carbon materials and non-corrosive materials fulfill all the above basic meet of electrodes. Carbon materials as carbon paper, carbon cloth, carbon felt, reticulated vitreous carbon (RVC), graphite rod and graphite brush and they may have plane, packed and brush configuration. Due to excellent high electrical conductivity, good chemical conductivity and relatively low cost are widely used in MFCs. Carbon paper and carbon cloths are plane-type of electrode. They improve the performance of MFC by reduction in the distance between two electrodes. The power density was $40 \mathrm{mWm}^{-2}$ with carbon paper as anode in dual-chamber MFC [6] while in single-chamber MFC it was $483 \mathrm{mWm}^{-2}$ with carbon cloth [7]. Carbon cloth is more porous and allows more surface area for the growth of bacteria. Graphite rod has high conductivity and provides maximum power $26 \mathrm{mWm}^{-2}$ with $80 \%$ COD removal in single-chamber MFC [8]. The application of graphite rode is limited due to its low porosity and surface area for microorganism adsorption. These limitations can be overcome by using graphite felt instead of graphite rod and provides larger output due to its loose texture and increases surface area [9].Graphite brush is made of graphite fiber this is twisted around non-corrosive more conductive metal wires (titanium wire). It is efficient electrode to achieve maximum power density due to its high surface area, high porosity and low electrode resistance [10]. Reticulated vitreous carbon (RVC) is conductive, porous but due to its large resistance, is less frequently used in MFC.

\section{CATHODIC MATERIALS IN MFC}

Cathodic materials should have high redox potential so that it can easily capture the electrons. Cathodic material can be same as anodic materials such as carbon paper, carbon cloth and graphite [11]. To improve the performance, modification of cathode with Pt catalyst is most popular because it reduces cathodic reaction activation energy and increase in reaction rate. The power density was $150 \mathrm{mWm}^{-2}$ in graphite felt containing Pt and it was three times higher than that of pure graphite cathode [12]. Due to high cost of Pt metal, it limits its application in MFC. There are several attempts to reduce the cathode cost either by decreasing $\mathrm{Pt}$ loading or other non-Pt catalyst. The non-Pt catalysts of cathode in MFCs are shown in Table 3 and are cost effective. The oxygen reduction based catalyst, iron phthalocyanine (FePc) and CoTMPP were inexpensive and efficient alternative for MFCs. The $\mathrm{PbO}_{2}$ produced two -four times more power than that of Pt cathode. The result indicated that $\mathrm{PbO}_{2}$ could replace $\mathrm{Pt}$ cathode catalyst [13].

Table 3: Non-Pt catalyst of cathode

\begin{tabular}{|c|c|}
\hline Cathode materials & Type of catalyst \\
\hline Carbon cloth & $\mathrm{MnO}_{2}$ \\
\hline Graphite foils & Rutile \\
\hline Carbon cloth & $\mathrm{C} 0-\mathrm{OMS}-2$ \\
\hline Carbon Paper & $\mathrm{FePc}$ \\
\hline Carbon cloth & $\mathrm{CoTMPP}$ \\
\hline Carbon cloth & $\beta-\mathrm{MnO}_{2}$ \\
\hline
\end{tabular}

\section{MEMBRANES IN MFC}

Membrane and structural materials are and important parameter that directly affect the performance and cost of MFC. Membrane and catalyst contribute $80 \%$ of the total cost [14].The internal resistance of the membrane play an important role in performance of the system, membrane with high internal resistance decreased ion exchange and proton diffusion which lead to lower power density and current [15]. So, for selection of membrane, no oxygen diffusion (aerated cathodic chamber to anaerobic anodic chamber), high ionic conductivity, high proton conductivity, durability, chemical stability, low cost, low internal resistance and biofouling must be taken into account. The morphology, thickness, presence of functional group and thermal stability of the membrane are characterized by; Fourier-transform infrared (FT-IR), thermogravimetry (TGA), scanning electron microscopy (SEM), transmission electron microscopy (TEM), atomic force microscopy (AFM) , nuclear magnetic resonance (NMR) and Raman spectroscopy. The membrane performance is characterized by ion exchange capacity (IEC), water uptake, resistance and proton conductivity. Cation exchange membrane (CEM) is also referred as proton exchange membranes are commonly used in MFCs and have negatively charged groups such as $-\mathrm{COO}^{-},-\mathrm{SO}_{3}^{-},-\mathrm{PO}_{3}^{-}$in the cluster region.CEM can be classified as; perfluorinated, non-fluorinated and partially fluorinated membranes. Nafion, Flemion, Hyflon and Aquivion 
are perfluorosulfonic acid polymeric membrane in which backbone of polytetrafluoroethylene (PTFE) backbone with side chains of vinyl ether which terminate in sulfonic acid groups. Nafion membrane (Perfluorinated membranes), CEM, have high proton conductivity due to this it is widely used in MFCs. This type of membrane of is very costly $\left(\$ 1400 \mathrm{~m}^{-2}\right)$ and make them unfeasible for large scale application. It also transfers cations such as $\mathrm{K}^{+}, \mathrm{Na}^{+}, \mathrm{NH}_{4}^{+}, \mathrm{Mg}^{++}$at similar rates to protons. As a result, these species have higher concentration (105 times) than proton in cathodic chamber and causes $\mathrm{pH}$ decrease in chamber. Ultrex CMI 7000 is another CEM and commonly used in MFC [16]. It is strong acid cation exchange membrane with gel polystyrene cross linked with divinylbenzene with sulfonic acid groups. The anion-exchange membrane, bipolar membrane, glass fiber $(0.4 \mathrm{~mm}$ thickness), J-cloth, membrane based on ionic liquid, and ultrafiltration membrane can be also used as a separator in MFCs.

\section{Conclusion}

MFCs are a novel bioelectrochemical device that integrates wastewater treatment and bioelectricity generation. They have potential to mitigate the growing energy demand via a sustainable route. Various studies have revealed the significance of electrode material for improving the efficiency of MFC. Due to excellent high electrical conductivity, good chemical conductivity and relatively low cost, carbon materials as carbon paper, carbon cloth, graphite rod etc are widely used in MFCs. They improve the performance of MFC by reduction in the distance between two electrodes. A tremendous development has been made in terms of power output in MFCs by using effective and low cost PEMs. Some of the challenges faced by MFCs are internal resistance and biofouling. They needs to be addressed during designing a efficient MFC for bioelectricity generation.

\section{REFERENCES}

[1] Bretschger O, Osterstock JB, Pinchak WE, Ishii S, Nelson KE (2010). Microbial fuel cells and microbial ecology: applications in ruminant health and production research. Microbial Ecology. 59:415-427.

[2] You SJ, Zhao QL, Zhang JN, Jiang JQ, Wan CL, Du MA, Zhao SQ (2007). A graphite granule membrane-less tubular air-cathode microbial fuel cell for power generation under continuously operational conditions, Journal of Power Sources. 173: 172-177.

[3] Min B, Logan BE (2004). Continuous Electricity Generation from Domestic Wastewater and Organic Substrates in a Flat Plate Microbial Fuel Cell. Environmental Science and Technology. 38: 5809-5814.
[4] Tang RCO, Jang JH, Lan TH, Wu JC, Yan WM, Sangeetha T, Wang CT, Ong HC, Ong ZC (2020) Review on design factors of microbial fuel cells using Buckingham's Pi Theorem. Renewable and Sustainable Energy Reviews. 130: 109878.

[5] Liu H, Cheng SA, Logan BE (2005). Power Generation in Fed-Batch Microbial Fuel Cells as a Function of Ionic Strength, Temperature, and Reactor Configuration. Environmental Science and Technology. 39: 5488-5493.

[6] Kim JR, Jung SH, Regan JM, Logan BE (2007). Electricity generation and microbial community analysis of alcohol powered microbial fuel cells. Bioresource Technology. 98: 2568-2577.

[7] Wang X, Feng YJ, Lee H (2008). Electricity production from beer brewery wastewater using single chamber microbial fuel cell. Water Science \& Technology. 57: 1117-1121.

[8] Liu H, Ramnayanan R, Logan BE (2004). Production of Electricity during Wastewater Treatment Using a Single Chamber Microbial Fuel Cell. Environmental Science and Technology. 38: 2281-2285.

[9] Chaudhuri SK, Lovley DR (2003). Electricity generation by direct oxidation of glucose in mediatorless microbial fuel cells. Nature Biotechnology. 21: 1229- 1232.

[10] Logan B, Cheng S, Watson V, Estadt G (2007). Graphite Fiber Brush Anodes for Increased Power Production in Air-Cathode Microbial Fuel Cells. Environmental Science and Technology. 41: 3341-3346.

[11] Zhou M, Chi M, Luo J, He H , Jin T. (2011). An overview of electrode materials in microbial fuel cells. Journal of Power Sources. 196: 4427- 4435.

[12] Moon H, Chang IS, Kim BH (2006). Continuous electricity production from artificial wastewater using a mediator-less microbial fuel cell. Bioresource Technology. 97:621-627.

[13] Morris JM, Jin S, Wang JQ, Zhu CZ, Urynowicz MA (2007).Lead dioxide as an alternative catalyst to platinium in microbial fuel cells. Electrochemistry Communication. 9:1730-1734.

[14] Torres CI, Krajmalnik-Brown R, Parameswaran P, Marcus AK, Wanger G, Gorby YA, Rittmann BE(2009). Selecting anode-respiring bacteria based on anode potential: Phylogenetic, electrochemical, and microscopic characterization. Environmental Science and Technology. 43: 9519-9524.

[15] Leong JX, Daud WRW, Ghasemi M , Liew K B, Ismail M. (2013). Ion exchange membranes as separators in microbial fuel cells for bioenergy conversion: A comprehensive review. Renewable and Sustainable Energy Reviews. 28: 575-587.

[16] Rozendal R, Sleutels T, Hamelers H, Buisman C (2008). Effect of the type of ion exchange membrane on performance, ion transport, and $\mathrm{pH}$ in biocatalyzed electrolysis of wastewater, Water Science \& Technology. 57: 1757-1762. 